\title{
Food item selection of Hanuman Langur (Presbytes entellus) in different season in Char-Koshe jungle of eastern Terai, Nepal
}

\author{
Shaligram Adhikaree ${ }^{1^{*}}$ and Tej Kumar Shrestha ${ }^{2}$ \\ ${ }^{I}$ Department of Zoology, Post Graduate Campus, Tribhuvan University, Biratnagar \\ ${ }^{2}$ Central Department of Zoology, Tribhuvan University, Kirtipur, Kathmandu \\ *E-mail: shaligram_adhikaree@yahoo.com
}

\begin{abstract}
Common langur was found to be a mixed feeder. 33 species of plants were found to be consumed and 16 more species were said to be consumed in that locality. Most of the plants were consumed during fruiting and flowering seasons. Most preferred (frequently used) plants were Terminalia belarica, Geruga pinnata, Spathalobus parviflora, Ficus bengalensis, Schlichera oleosa, Ficus glomerata, Diospyrus tomentosa, Terminalia tomentosa, Emblica officinalis etc. On the basis of time spent to consume, fruit and seed comprised of about $56 \%$, flower, leaf-bud, young leaves $29 \%$, and mature leaves, bark and petiole $15 \%$ of annual budget of diet. Amount of different items in different seasons vary according to availability of first item (fruits and flower) and second items (new growths and leaf-bud). Fruits constitute more than $83 \%$ of diet during month of monsoon. Insectivory was not observed except during grooming. The langurs were not reported to raid the crops in vicinity.
\end{abstract}

Key words: Presbytes entellus, Langur, food selection, Nepal

\section{Introduction}

Common langur (Presbytis entellus) is locally known as "Dhendu". It is most common in Charkose Jhadi. They are found in Nepal, India, Bhutan, Bangladesh and Sri-Lanka. It is quite a big creature, weighing 35-50 Lbs; head and body measure from 2-2.5 feet and its tail up to 3.5 feet long. Most of its fur is greyish white in contrast of its black face and palm soles and callosities on the buttocks. The juvenile colour changes in order from black, brown to light grey and slate grey. Langurs usually live in bisexual troops (Roonwal \& Mohnot, 1977; Shrestha, 1997).

They begin feeding at dawn and after some hours of rest around mid day they start again in afternoon. Their diet consists of fruits, leaves, buds, flowers, pith and bark of tender branches. As they inhabit many different habitats from sea level to an altitude of $4000 \mathrm{~m}$ in the himalayan-region (Bosries et al., 1993), the species and parts of plants chosen for food vary from area to area and season to season. Only, very little works have been done to study the food of sacred langur in forest habitat. Present study was carried out to study on the food item selection by common langur in the jungle (Char-Kose-Jhadi) of southeast Nepal.

Study area lies approximately at $10 \mathrm{~km}$ south of Dharan on the southern part of Charkose Jhadi near the crossing point of $87^{\circ} 15^{\prime} \mathrm{E}$ and $26^{\circ} 45^{\prime} \mathrm{N}$ on a north to south facing slop. Altitude of study area varies approximately from $120 \mathrm{~m}$ to $250 \mathrm{~m}$ above 
sea level within approximate distance of $6 \mathrm{~km}$. Gradient of inclination is higher at northern part of study area. Western, northern and eastern boundaries of study area are made up by Jhepre Khola (river), large fire-line and partly highway and partly Seuti Khola (river) respectively in jungle and villages Panchayan Jhoda and Kumar Khat lies on the southern border of the study area.

\section{Materials and Methods}

\section{Identification}

Photographs and samples of plants used as food by common langur were routinely collected and unidentified specimens were preserved for latter identification. Verbal informations about the food plants of langure were collected from local people. Routine observation of feeding habit for all 12 months of year starting from April, 1995 to March, 1996 was carried out.

\section{Preference of different items}

Estimates of preference of different items in the diet were based on numbers of individuals feeding on particular item and the relative length of feeding period. During the study period, 3 days of the each month were taken (by systematic random sampling) as the sampling days. Observation of feeding activities of different troops at different time was recorded. Foods were divided in 3 items viz., item A for fruits and seeds; item $B$ for flower, young leaf, leaf bud and new growth; and item $\mathrm{C}$ for mature leaf, bark and petiole.

Length of feeding period in minute and number of individuals feeding on particular item of diet were noted and product was calculated. Preference on different food items in the diet in different seasons were calculated on the basis of time individuals. For this purpose a year

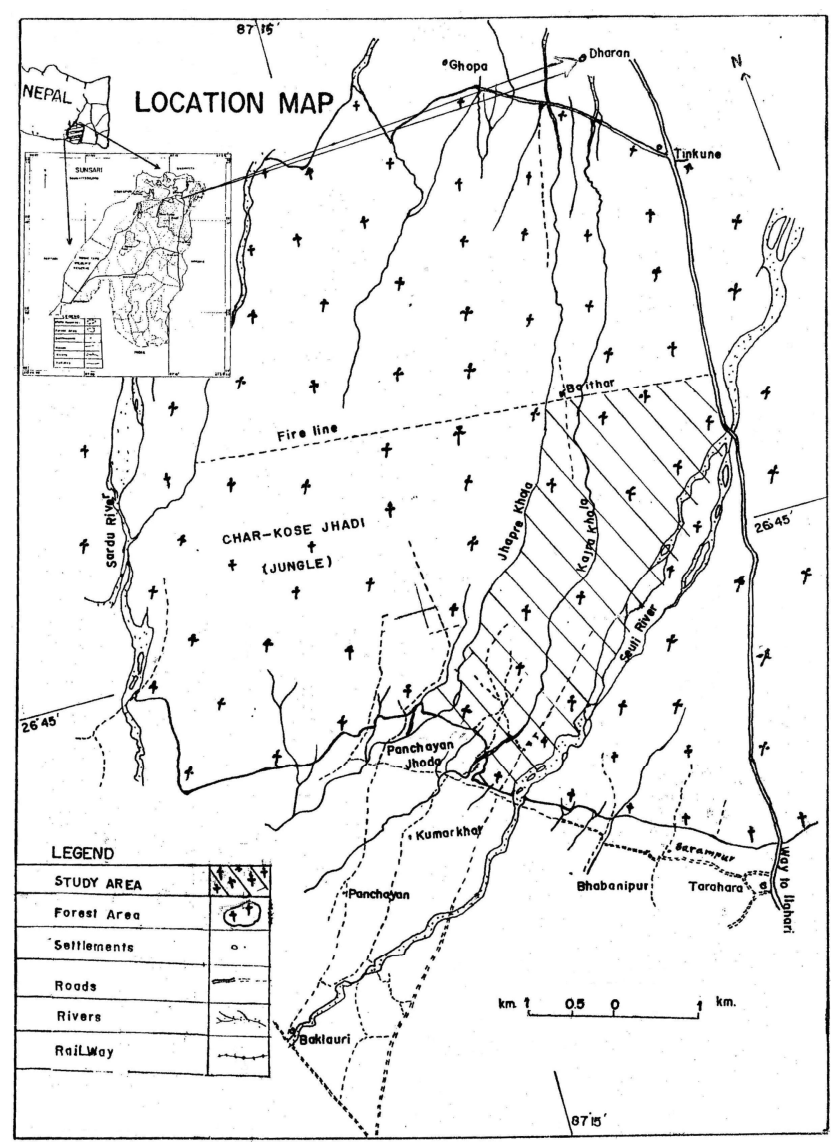
was divided into three seasons viz., winter (November to February), summer (March to May) and monsoon (June to October).

Test of significance of preference of different items in different season was carried out by the chi-square $\left(\chi^{2}\right)$ test in $3 \times 3$ contingency table. 


\section{Results and Discussion}

The langur is a leaf-eating monkey. Unlike Macaques, the stomach of langurs replace the work of check pouch (Prater, 1972). The stomach consists of three separate pouches or compartments like that of a ruminating animal, suited to their special feeding habit. The staple diet includes fruits, flowers, buds shoots and leaves (Prater, 1972; Jackson, 1990). They were known to consume items even avoided by insects with too high alkaloid levels (Jackson, 1990). In the mountains and hills, langurs were predicted to feed on the fruits, flowers and leaves of common species like Rododonodron spp., Qurercus spp., Castanopsis spp., Mationia nepalensis and Primus spp. (Gurung, 1993). His prediction was based on observation and interviews.

In the study area, langurs were observed to feed on 33 species of common plants (Table 1). Langurs were said to feed on 16 more plant species (Table 2) according to local information but not reported to destroy cultivation presumably because of afraid of dogs and it may be due to availability of foods elsewhere in the jungle. Fruits were the staple diet of common langur in the study area, which was estimated about $56 \%$ of annual budget.

Table 1. Plants used by Common Langur in different months. “*” indicates consumption.

\begin{tabular}{|c|c|c|c|c|c|c|c|c|c|c|c|c|c|c|}
\hline \multirow{2}{*}{ SN Scientific Names } & \multirow{2}{*}{$\begin{array}{c}\text { Vetrnacular } \\
\text { name }\end{array}$} & \multicolumn{12}{|c|}{ Months of consumption } & \multirow{2}{*}{-Part consumed } \\
\hline & & $\mathrm{J}$ & $\mathrm{F}$ & $\mathrm{M}$ & $\mathrm{A}$ & $\mathrm{M}$ & $\mathrm{J}$ & $\mathrm{J}$ & $\mathrm{A}$ & $\mathrm{S}$ & 0 & $\mathrm{~N}$ & $\mathrm{D}$ & \\
\hline 1 Anthocephalus cademba & Kadam & & & & & & $*$ & $*$ & $*$ & $*$ & $*$ & & & Flower \& fruits \\
\hline 2 Antidesma burn us & Archal & & $*$ & & & & $*$ & & $*$ & & & & $*$ & Fruit leaf \\
\hline 3 Bhduhenia purptirra & Tanki & $*$ & $*$ & & & $*$ & & & $*$ & $*$ & & & & Flower \& leaf \\
\hline 4 Bhauhenia vhalii & Bhorla & & & $*$ & $*$ & $*$ & & & & & & & & Buds, young seed \\
\hline 5 Biscofia javanica & Kainjal & $*$ & $*$ & & & & & & & & & & & Fruit \\
\hline 6 Bridelia retura & Gayo & $*$ & $*$ & & & & & & & & & & & Fruit \\
\hline 7 Cicca acida & Pateamala & & $*$ & $*$ & $*$ & & & & & & & & & Fruit \\
\hline 8 Cochlospemum religiosum & Kumbhi & & $*$ & $*$ & $*$ & & & & & & & & & Young leaves, flower \\
\hline 9 Dillenia pentagyna & Tantari & & & & & $*$ & $*$ & & & & & & & Fruit \\
\hline 10 Emblica officinalis & Amala & $*$ & $*$ & & & & & & & & $*$ & $*$ & $*$ & Fruit \& leaf \\
\hline 11 Eugenia operculata & Kyaimuna & & & & & & $*$ & & & & & & & Fruit \\
\hline 12 Ficus bengalensis & Bar & & & & $*$ & $*$ & $*$ & & & & & & & Fruit \\
\hline 13 Ficus cunia & Khaniu & & & & & & & & & $*$ & $*$ & $*$ & $*$ & Fruit \& leaf \\
\hline 14 Ficus glomerata & Dumri & & & & $*$ & & & $*$ & $*$ & $*$ & & & & Fruit \& leaf \\
\hline 15 Ficus hispida & Khashreto & & & & & & & $*$ & * & & & & & Fruit \\
\hline 16 Ficus lacor & Kavro & $*$ & $*$ & $*$ & $*$ & & & & & & & $*$ & $*$ & Leaf-bud \& leaf \\
\hline 17 Geruga pinnata & Dabdabe & & & $*$ & $*$ & & $*$ & $*$ & $*$ & $*$ & $*$ & $*$ & & Flower, fruit, leaf \\
\hline 18 Loranthus faleons & Ainjeru & $*$ & & $*$ & & & & & & & $*$ & $*$ & $*$ & Soft base of leaf \\
\hline 19 Murraya koenigii & Asare & & & & & & $*$ & * & & & & & & Fruit \\
\hline 20 Diospyrus tomentosa & Kalikath & & & & & $*$ & $*$ & * & & & & & & Fruit \\
\hline 21 Qphioglossum volgatum & Jibre-Sag & & & & & & & $*$ & & & & & & Whole plant \\
\hline 22 Psidium guajava & Ambak & $*$ & & & & & & & $*$ & $*$ & $*$ & & $*$ & Bark \& fruit \\
\hline 23 SchIcichera oleosa & Kusiim & & & & & & & $*$ & $*$ & & & & & Fruit \\
\hline 24 Shorea robusta & Sal & & & $*$ & * & $*$ & $*$ & & & & & & & Seed, young leafs \\
\hline 25 SpathoJobus parvi flora & Debre-lahare & & $*$ & $*$ & $*$ & $*$ & & & $*$ & & & $*$ & & Leaf, buds \\
\hline 26 Spondias cyntherica & Amaro & & & & & & & & & $*$ & $*$ & & $*$ & Fruit \& petiole \\
\hline 27 Stereospermum tetragonum & Padari & $*$ & & & & & & $*$ & & $*$ & $*$ & & $*$ & Leaf \& buds \\
\hline 28 Syzygium cumini & Jamun & & & & & & $*$ & $*$ & $*$ & & & & & Fruit \\
\hline 29 Terminalia belarica & Barro & $*$ & $*$ & $*$ & $*$ & $*$ & $*$ & & $*$ & & $*$ & $*$ & $*$ & Fuit \& petiole \\
\hline 30 Terminalia chebula & Harro & & & & & & & & & $*$ & $*$ & $*$ & & Fruit \\
\hline 31 Terminalia tomentosa & Saj & $*$ & $*$ & & & $*$ & & & & $*$ & & $*$ & $*$ & Fruit \& leaf \\
\hline 32 Uvaria hamiltonii & Banar-Jhilla & & & & & & & & $*$ & $*$ & & & & Fruit \\
\hline 33 Artocarpus sp & Lathar & & & & & & $*$ & $*$ & & & & & & Fruit \\
\hline
\end{tabular}


Table 2. Additional plants said to be consumed by Langur.

\begin{tabular}{clll}
\hline SN & Scientific name & Nepali name & Part consumed \\
\hline 1 & Alphonsia ventricosa & Thekiphal & Fruit \\
2 & Anocarpus lakoocha & Badahar & Leaf flower, fruit \\
3 & Bornbax malbaricwn & Simal & Flower, young fruit, seed \\
4 & Ficus religiosa & Pipal & Flower, young fruit, seed \\
5 & Gmelina arboria & Khamari & Fruit \\
6 & Grewia elastica & Syalphoshara & Fruit \\
7 & Lagestromia parviflora & Botdhayenro & Fruit \\
8 & Lyonia ovalifolia & Angeri & Fruit, flower \\
9 & Mangifera indica & Aanp & Fruit \\
10 & M. sylvatica & Ban Aanp & Fruit \\
11 & Melia azederach & Bakaino & Fruit \\
12 & Sambucus hookeri & Galeni & Fruits \& leaves \\
13 & Semecarpus anacardium & Bhalayo & Fruit \\
14 & Zizyphus sp. & Bayar & Fruit and leaves \\
15 & Clausena excavata & Paineti & Fruit and leaves \\
16 & - & Chyau & Whole plant (mushroom) \\
\hline
\end{tabular}

According to Roonwal and Mohnot (1977), Presbytis entellus was entirely vegetarian, eating mainly leaves, and also shoots, buds, flowers, bark, fruits and seeds of large number of plants. Only rarely does it eat insects. Cultivated crops and vegetables were also taken whenever available. In certain areas in the vicinity of cities and towns, people feed the langur uncooked and cooked food including Chapatis (flat cakes) of wheat, Bajra (a millet) and many other types of food (gram, groundnuts etc.) which the Hanuman langur eats with relish. More than one group may feed together. In entirely unforced forest settings, common langurs frequently feed amicably in large composite troops of several groups, in the tree tops and the ground.

Langur is frugivours. When fruits were not available, it takes flowers of Madhuca (Mahua) and Salmalia (Semal), leaves of Randalia (Mayan), shoots and buds of Ficus glomerata (Gular), fruits of Syzigium, Ficus religisa, Myrica, Erythrina and Zizyphus sp. (Bhatta \& Shrestha, 1977). Fruits of Ficus glomerata were highly favoured by both ungulates and monkey in mixed riverine forest, where this species was dominant. Difference between the foraging strategies of langur and rhesus troop in KarnaliBardia was evident. Langurs were almost exclusively arboreal feeders while rhesuses were more terrestrial as shown by the inclusion of ground insects and spiders in their diets (Dinerstein, 1979). While both species were highly frugivorous, the langur has become an important folivore through the evolution of a ruminant like digestive system (Bauchop \& Martucci, 1968). According to Gurung (1983), their diet consists of shoot, leaves, buds, flowers, fruits and the pith of tender branches in Royal Chitwan National Park.

According to Borries et al. (1993), at Ramnagar, the ecological conditions cause a high fluctuation of food availability and quality in the course of a year. Food availability seems to be highest in spring, prior to the monsoon, when the trees blossom and fresh leaves appear every where. In the cold months mostly mature leaves and few fruits were left. That seems to be sufficient to cover the basic needs of the langur except females in late pregnancy and early lactation period though they also can digest even mature leaves.

In Peninsular India, Krishnan (1972) reported over 30 species of food plants of whose leaves, leaf buds, shoots, flowers and fruits were consumed by Langur. According to 
Roonwal and Mohnot (1977), its diet consists of about 65\% fruits and 35\% leaves and flower buds. The species and parts of plants chosen for food vary from area to area and season to season. In the hills of Mount Abu in southern Rajasthan, it eats the leaves, buds and flowers of several plants including Acacia arabica, Bombax malabaricum, Dalbergia sissoo and Ficus glomerata. In eastern Rajasthan it prefers the leaves and fruit of Zizyphus jujuba and the leaves of Anogeissus pendala. At the eastern edge of Thar desert, western Rajasthan, it eats virtually all available plants with the notable exception of the abundant herb Leptademia phyrotechnica. Mohnot recorded 80 plants whose leaves fruits, buds and flowers were eaten, leaves constituting the bulk. The plants most preferred were: Prosopis juliflora, Ficus bangalensis, $F$. religiosa, Salvadera persicd, Acacia senegal and Zizyphus nummularia. In addition it attacks gardens, archards and vegetable fields in the vicinity of Jodhpur, where it feeds on a large number of trees herbs, shrubs, vines, and cultivated vegetables (Roonwal \& Mohnat, 1977).

In the Gir forest, Gujarat, 41 plants were recorded whose leaves and flowers the common langur feeds. In southern India important food plant includes Zizyphus, Phylanthus embilica and Cacia auriculata. In the dry season when the leaves were dry or absent, it lives mainly on fruits buds and bark. It occasionally eats caterpillars and indirectly the insects found inside plant galls. In Uttar Pradesh, it eats leaves, flowers and berries of Lantans (Lantana camera) as well as leaves of Terminalia tomentosa and many other species of trees. In the Himalayas it feeds on Eugenia jambolana, Trewia nudiflora, Acacia concinna and fruits of oak. In Ceylon, Ripley (1970) provisionally listed 57 species of food plants including large trees (both deciduous and evergreen) shrub, (climbing) vines and herbs. She also observed common langurs eating spider's webs and earth from termite mounts (Roonwal \& Mohnat, 1977).

The feeding time data suggested that mature leaf constituted $34.9 \%$, fruit $24.5 \%$, leaf bud $10.7 \%$, flower-bud $6.6 \%$ and young leaf $3.6 \%$ of the annual budget (Newton, 1985). One percent of feeding time was found to be spent on feeding gums. Out of 68 species of trees and climbers, the troop fed on 53 species. The most important in terms of percent time spent feeding, were Pterocarpus mersupium, Shorea robmta, Bunhinia retusa and Anogeissus latifolia. The undergrowth shrub Flamengia semilata was also seasonally important.

Mathur and Manohara (1987) presented list of 25 trees (both mature leaves and young leaves of 23 species, fruits of 6 , petiole of 4 , flower of 3 and bark of one species) exploited by common langur of Galta area in Jaipur, India. Some groups were seldom fed by human beings. They considered some of them as pests. Chaudhari and Roy (1989) have studied the survival status of hunuman langur in some villages of Nadia district, West Bengal. They observed different plants and parts of nine plants were being consumed as major food.

Common langur also regularly licks stones and hard earth from termite mounds or even breaks pieces of earth with the hand and eats them. Evidently this is done to obtain its' requirements of salts and minerals such as calcium, magnesium and trace elements (for example copper). For this purpose, Vogel (1971) noted the special licking places. Roonwal and Mohnot (1977) observed common langurs eating earth and ashes and bones from cremation ground; Ripley (Roonwal \& Mohnot, 1977) reported that mortar from old buildings and earth from termite mounds were eaten. Newton (1985) also noted earth eating especially of termite-reworked soil. 
Davies and Baillie (1988) observed geophagy in Presbytis rubicunda. Soil was always collected by breaking lumps of termitaria and never from the forest floor. Termitaria mount soil was of highest $\mathrm{pH}$ and had higher level of the main cationic nutrients and lower level of the labile aluminum. Similarly, Moe (1993) found that common langur (Presbytis entellus) was one of the most common species on the soil lick during the dry season in low land. Most common langur used to lick intensively in March after flushing of browse species. Only sodium concentration and $\mathrm{pH}$ were significantly higher than control soil sample. Insect eating habit in different habitat seems to support the "Energy/nutrient maximization" hypothesis. Newton (1985) observed $2.8 \%$ of feeding time as insectivore. Common langur can eat the fruit including seeds of Strychnos non-vomica, the plant from which the poison strychnine is made. It was observed that dose of strychnine that kill rhesus macaques had no effect on Hanuman langur. It also eats apparently without ill effects, such repulsive and evil smelling latex-bearing plant as the ank Calotropis procera in the Indian desert and C. gigantea in Ceylon which were avoided by most animals and even insects (Roonwal \& Mohnot, 1977).

Langur occasionally fed on ticks, lice and grass hoppers (Mathur et al., 1990). Srivasthava (1992) observed insectivore in open scrub forest of Jodhpur. His observations reveal that scale insects may constitute a regular part of their diet and that insectivory was particularly prevalent in the monsoon months July-September. But, Insectivory was not observed except during grooming in the study area. The langurs were not reported to raid the crops in vicinity of the study area.

Common langur at the study area utilized a wide range of trees, shrubs, climbers and herbs. Out of 33 utilised species, most preferred plants were Terminatia belarica, $I$. tomentosa, Geruga pinnata, Stereospermum tetragonum, Ficus bengalensis and Spatholobus parviflora (Table 1). Plant species utilized by common langur in different place varied according to availability. Other plants said to be consumed were rare (Table 2) and some of them e.g., fruits of Mangifera spp. were utilized by man and not left for wild animals. Most preferred food item was wild fruits. Second preference of langur was new growths like leaf-buds, young leaves, and soft parts like flowers and petioles. Lastly, they take mature Ieaves, bark and resin. Their preference towards fleshy and soft part is presumably because of high content of water and low content of fibbers.

Table 3. Preference of Common Langur on different food items.

\begin{tabular}{ccccccccc}
\hline \multirow{2}{*}{ Food Items } & $\begin{array}{c}\text { Winter: Oct-Feb } \\
\text { (5 months) }\end{array}$ & \multicolumn{2}{c}{$\begin{array}{c}\text { Summer: March- } \\
\text { May (3 months) }\end{array}$} & $\begin{array}{c}\text { Monsoon: Jun-Sep. } \\
\text { (4 months) }\end{array}$ & Total (12 months) \\
\cline { 2 - 9 } & $\mathrm{T}$ & $\mathrm{P}$ & $\mathrm{T}$ & $\mathrm{P}$ & $\mathrm{T}$ & $\mathrm{P}$ & $\mathrm{T}$ & $\mathrm{P}$ \\
\hline Item A & 16156 & 40.1 & 11680 & 46.28 & 27625 & 83.42 & 55461 & 56.23 \\
Item B & 12828 & 31.9 & 11343 & 44.94 & 4279 & 12.92 & 28450 & 28.85 \\
Item C & 11291 & 28 & 2216 & 8.78 & 1210 & 3.65 & 14717 & 14.92 \\
Total & 40275 & 100 & 25239 & 100 & 33114 & 100 & 98628 & 100 \\
\hline
\end{tabular}

Item $\mathrm{A}=$ Fruits $\&$ seeds, Item $\mathrm{B}=$ Flowers, new growths, leaf -buds $\&$ young leaves, Item $\mathrm{C}=$ Mature leaves, bark \& petioles, $\mathrm{T}=$ Time individual, $\mathrm{P}=$ Preference $(\%)$

Seasonal variation in proportion of food items or degree of dependency on different food items was distinct. Dependency on food item A varies from $40 \%$ in winter to $83 \%$ in monsoon. Item B was important during summer and winter. Dependency on it was approximately $45 \%$ in summer, nearly $32 \%$ in winter and only $12.9 \%$ in monsoon. Dependency on item C varies from $28 \%$ in winter to $3.65 \%$ in monsoon. In 
other words, Langur about equally depends on all 3 food items in winter, mainly depends upon item A and B in summer and heavily depends upon fruits during monsoon (Table 3, Fig. 1). Chi-square test of seasonal variation of time-individuals feeding on particular food items shows highly significant $(\mathrm{p}<.01)$.
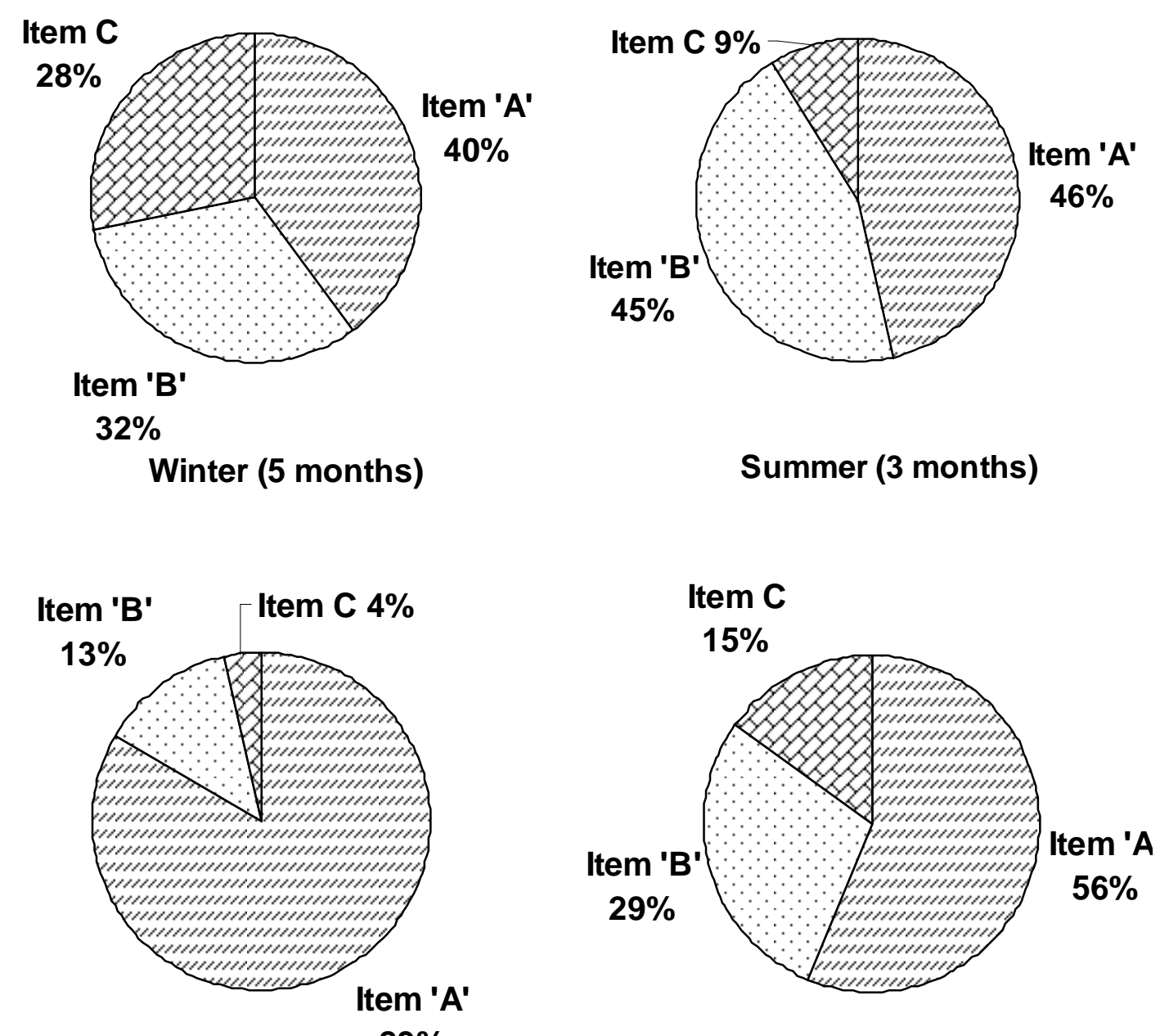

Monsoon (4 months)

Total 12 months

Figure 1. Preferences of Common Langur among different food items.

\section{Acknowledgements}

Authors are thankful to the Central Department of Zoology for providing the facilities to carry out the present work.

\section{References}

Bauchop, T. \& R.W. Martucci. 1968. Ruminant-like digestion of the Langur Monkey. Science, N.Y. 161: 698-699.

Bhatta, D.D. \& T.K. Shrestha. 1977. The Environment of Suklaphanta. Curriculum Development Centre, T.U. Kathmandu Nepal. 80 p.

Borries, C., M.K. Giri, D. Padzuweit \& M.K. Chalishe. 1993. Social flexibility in Common Langur Monkeys (Presbytis entellus). Nahson Bull. NAHASON, Nepal. 2(1): 3-5. 
Davies, A.G. \& I.C. Baillie. 1988. Soil eating by Red Leaf Monkeys (Presbytis mbiconda) in Sabah, Northern Barneo. Biotropica 20(3): 252-258.

Dinerstein, E. 1979. An ecological survey of the Royal Karnali-Bardia Wildlife Reserve, Nepal. Part: II. Habitat/Animal interactions. Bio. Conserv. 16: 265-300.

Gurung, K.K. 1983. Heart of the Jungle, the wildlife of Chitwan, Nepal. Andra Deutsch. London.

Gurung, M.K. 1993. An assessment of the habitat models to predict distribution and habitat pattern of large mammals in the Annapurna area. M.Sc. Thesis, Central Department of Zoology, T.U., Nepal.

Jackson, R. 1990. Threatended wildlife, crop and wildlife depredation and grazing in the Makalu-Barun Conservation area. Working paper publication services, Report 12. Prepared for the Makalu-Barun Conservation Project. Kathmandu.

Krishnan, M. 1972. An ecological survey of larger mammals of Peninsular India. J. Bomb. Nat. Hist. Soc. 69: 469-501.

Mathur, R. \& B.R. Manohar. 1987. Group number and composition of Hanuman Langur (Presbytis entellus) in Jaipur, India. J. Bomb. Nat. Hist. Soc. 84: 193-199.

Mathur, R., P.S. Bhatnager \& B.R. Manohara. 1990. Ticks lice and grasshopper eating in Presbytis entellus. Human Evol. 56: 531-536.

Moe, S.R. I993. Mineral content and wildlife use of soil licks in south western Nepal. Can. J. Zool. 71(5): 933-936.

Newton, P.N. 1985. The behavioral ecology of forest Hanuman Langurs. Tiger Paper 12(3): 3-7.

Prater, S.H. 1972. The book of Indian mammals. Bombay Natural History Society, Bombay.

Ripley, S. 1970. Leaves and leaf monkey. In: Old World Monkey (Eds. J. Napier \& P. Napier). Academic Press, New York.

Roonwal, M.L. \& S.M. Mohnot 1977. Hanuman Langur. In: Primates of South Asia Ecology, Sociobiology and Behaviour (Eds. M.L. Roonwall \& S.M. Mohnot). Harvard University Press. Chicago.

Shrestha, K. 1984. A field guide to Nepali names for plants ( $2^{\text {nd }}$ ed.). Natural History Museum, Institute of Science and Technology, Tribhuvan University. Kathmandu, Nepal.

Shrestha, T.K. 1997. Mammals of Nepal. Kathmandu.

Srivastava, A. 1992. Insectivory and its significance to Langur diets. Primates 32(2): 237242.

Vogel, C. 1971. Behavioral differences for Presbytis entellus in two different habitats. Proceedings of Third International Congress of Primatology, Zurich. 1970/3: 4147. 